Bryn Mawr College

Scholarship, Research, and Creative Work at Bryn Mawr College

Classical and Near Eastern Archaeology Faculty

Research and Scholarship

Classical and Near Eastern Archaeology

1971

\title{
A Replica of the "Barberini Suppliant" Head in New York
}

E. Herscher

Brunilde S. Ridgway

Bryn Mawr College, bridgway@brynmawr.edu

Let us know how access to this document benefits you.

Follow this and additional works at: http://repository.brynmawr.edu/arch_pubs

Part of the Classical Archaeology and Art History Commons, and the History of Art, Architecture, and Archaeology Commons

\section{Custom Citation}

Herscher, Ellen, and Brunilde S. Ridgway. 1971. A Replica of the "Barberini Suppliant" Head in New York. American Journal of Archaeology 75:184-188.

This paper is posted at Scholarship, Research, and Creative Work at Bryn Mawr College. http://repository.brynmawr.edu/arch_pubs/71

For more information, please contact repository@brynmawr.edu. 
it are the letters $] \sigma$ as $\delta \iota \pi \lambda a s \delta[$, and Jacobsthal concludes that this is part of a reference to the twostoreyed porticoes which frame the gymnasium. While this is obviously a reasonable explanation, there is no definite indication that $\sigma \tau$ oòs was the noun which $\delta \iota \pi \lambda \hat{a}$ s qualified. Elsewhere the sense two-aisled stoa fits the context of the phrase $\delta \iota \pi \lambda \hat{\eta} \sigma \tau o a$ very well. An inscription from the territory of Philadelphia in

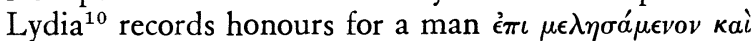

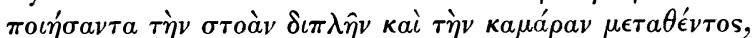
and perhaps the easiest way of "doubling" a stoa would be by adding a second aisle in front of ${ }^{11}$ or behind $^{12}$ the existing one. At Priene, where a $\delta \iota \pi \lambda \hat{\eta}$ $\sigma \tau o a ́$ is mentioned in an inscription of c. 200 B.C., ${ }^{13}$ there is no back-to-back stoa ${ }^{14}$ or two-storeyed stoa known, but there definitely was at that time a twoaisled portico on the agora, ${ }^{15}$ the middle part of the South Stoa. In general two-aisled stoas are quite widespread, although not so common that the use of $\delta i \pi \lambda \hat{\eta}$ in this sense would never serve to identify one particular stoa in a city. In contrast to this, stoas with two porticos back-to-back are rare ${ }^{16}$ and two-storeyed stoas also have a restricted distribution, limited normally to the sphere of Pergamene influence. ${ }^{17}$

The evidence thus suggests that although $\delta \iota \pi \lambda \hat{\eta} \sigma \tau o a$ ' need not always have meant the same thing, it was normally used of a two-aisled stoa or portico.

UNIVERSITY OF EDINBURGH

J. J. Coulton

\section{A REPLICA OF THE "BARBERINI SUPPLIANT" HEAD IN NEW YORK}

PLATE 45

The head which forms the subject of the present study has never been extensively published; except for

10 Hellenica 9 (1950) 28.

11 This was done to the portico of the East Building of the South Market at Miletos, and perhaps also, H. A. Thompson suggests, to the south portico of the Market of Caesar and Augustus at Athens.

12 Similarly, a portico facing in the opposite direction was added behind the original Stoa of Philip at Delos.

${ }^{13} \mathrm{~F}$. Hiller von Gaertringen, Inschriften von Priene (1906) no. 49 ; cf. $J d I 49$ (1934) ro6.

14 The Stoa by the Temple of Athena was not built in 200 B.c. (Priene 1 28-129), and in any case, although it may have had two colonnades, its portico was definitely single, and $\sigma \tau o a ́$ refers to a portico, not simply a colonnade.

15 The Early North Stoa probably also had two aisles (Priene 215-216).

16 The only stoas of this type known from excavation are the South Stoa at Elis (?), the Stoa of Philip at Delos, the Middle Stoa at Athens and perhaps the South Stoa at Thermon.

17 The only pre-Roman stoas with upper and lower porticoes (not just a portico on a basement) outside the sphere of Pergamene influence are the East Stoa at the Asklepieion at Athens and the Stoa by the Harbour at Perachora. Other possible examples at Corinth (North Stoa III and North Building) are unlikely. Further examples are known from the Roman period, for instance the Northwest Stoa at Corinth and the South Lshaped Stoa of the North Market at Miletos (the latter an example of a stoa being "doubled" in a vertical sense by the addition of an upper portico). the listing in the catalogue of a Fogg Museum exhibit in 1954 , it has received only brief mention in footnotes which summarily dismiss it as a forgery. ${ }^{1}$ Unfortunately other replicas of the same head-type exist whose authenticity can legitimately be doubted, ${ }^{2}$ and therefore the same judgment tends to be extended to all extant copies. We believe instead that the head in New York is genuine and are most grateful to the owner, Dr. Iris C. Love, who has so generously granted us permission to publish the piece in her collection. ${ }^{3}$

The New York head was acquired by Dr. Love's father, C. Ruxton Love, presumably from Ernst Brummer, and may have once been owned by Ludwig Curtius. This former ownership alone would strongly speak in favor of authenticity, since Curtius was a noted connoisseur of ancient art, but unfortunately the information cannot now be substantiated. In 1954 the Love head was loaned to the Fogg Art Museum as part of an exhibition of Ancient Art in American Private Collections. On that occasion the piece was cleaned, presumably with acid; as a result much of the original surface was removed and the marble appears now in the granulose condition of a lump of sugar which has been subject to the action of water. Furthermore, this porous surface has attracted and absorbed the dust and smog everpresent in the atmosphere of New York City, so that the head is now streaked and blotched with dirt impossible to remove by ordinary means. We also understand that the piece has acquired an overall soft effect which it did not have when it first came into possession of the Love family. ${ }^{4}$

Except for the damage to the original surface, the head is in a remarkable state of preservation. It was broken off, presumably from a complete statue, ap-

1 Ancient Art in American Private Collections, The Fogg Art Museum, Cambridge, Mass., I954 (Exhibition, Dec. 28, 1954Feb. I5, I955); no. I5I (entry by G. M. A. Hanfmann). For mentions of the Love head as a forgery see W. H. Schuchhardt, Gnomon 30 (I958) 490; J. Dörig, "Kalamis-studien," JdI 80 (1965) I65 ก. 1 27.

2 See Dörig (supra n. r), and cf. especially E. Paribeni, Sculture Greche del V Secolo (Rome 1953) no. I 24 with illustration.

3 This paper developed from a graduate seminar report which Miss Herscher gave at Bryn Mawr College in November 1968. Dr. Love has kindly allowed repeated examination of the piece and has volunteered invaluable information not available in publications.

${ }_{4}^{4}$ The exact date of acquisition is not recorded, and the Brummer sale catalogues in existence make no mention of this specific piece. Enquiries of Mr. Brummer's widow have elicited no further information. Therefore the first definite record of the Love head is the Fogg Exhibit of 1954, which furnishes a date ante quem for its acquisition by the Love family.

The marble is coarse grained, white, probably of Italian origin. Measurements in cms.: greatest preserved ht. 27.8; ht. from dome to chin 23.7; ht. of face (hairline to chin) 15.3; greatest width 20.0 ; w. at temples 12.5 ; w. of cranium above ears 16.8 ; w. of neck 11.4 ; length of eye 3.0 ; length of mouth 3.7 ; distance between inner corners of eyes 3.I; distance between outer corners of eyes 9.9 ; distance from hairline to center of coiffure 14.6. 
proximately at the point of connection to the torso, with a fracture which split the neck in several pieces, now joined together. One portion of the neck, however, to the right of the central axis at the nape, is missing and is replaced in plaster. Other damage includes chipping of the nose tip and of the right ear rim. A curious depression on the skull, to the proper left of the hair part slightly above the fillet, would appear caused by a blow, but the hair strands, though faintly marked, cross over the depressed area and suggest either a reworking or, more probably, original carving over a flaw in the marble or a miscutting in the rendering of the hair waves.

Other interesting technical details include traces of a puntello, mostly smoothed off and cut into by the groove of a hair strand; it is located near the center of the crown toward the front, on the axis of the face. On the same axis but immediately below the hairline, over the forehead, a tiny pinprick suggests that this particular head might have been copied in antiquity: the hole would have been made by the pointing machine used to transfer the head's dimensions to an uncut block of marble. ${ }^{5}$ The chin, another important reference point for copyists, preserves no trace of a similar hole, perhaps because of the corrosion of the surface; but in the back a second hole, aligned with the first though not central to the hair pattern on the nape, appears above the roll of curls in the groove between two strands.

The alignment of this particular hole points out clearly the slightly twisted position of head and neck: the hole is placed on the central axis of the piece, but the inclination of the head to the proper left determines the shifting of the hair pattern toward the opposite side. The long strands radiate from a central point on the relatively high crown and run forward without a definite part, to divide only below the fillet, over the forehead. The locks are then loosely twisted around the ribbon which encircles the head, and form a prominent roll above ears and nape; in the back this arrangement determines a fork in the course of the strands above the roll, yet the intervening triangular area is not centered on the nape but dis-

5 A similar suggestion is made by E. B. Harrison for a head in the Athenian Agora, Hesperia 29 (1960) 370 pl. 81:a-b, inv. S 2094. It is unlikely that a forger would have added this detail.

${ }^{6}$ This effect has of course been increased by the modern cleaning.

${ }^{7}$ G. M. A. Hanfmann in the Fogg Exhibition Catalogue; see supra n. I. For the Luku Amazon type see E. Langlotz, Phidiasprobleme (Frankfurt 1947) pl. I6.

8 Barberini Suppliant: $\mathrm{BrBr} 5 \mathrm{I}_{5}$; details of the head in EA 483-484. The main publication of this statue is by E. Michon, MonPiot 35 (1935-36) I00-I 24. The measurements of the Louvre statue, as given by the Museum records, are: ht. of face (head?) 2 I.0; width of face 20.0; width of cranium 20.0.

The following measurements were taken directly by Miss Herscher and should be considered only as close approximations: distance between the eyes 3.0; length of mouth 4.2; distance between outer corners of eyes 7.5. On direct examination, the head of the Louvre statue seems somewhat smaller than the Love head; this would seem to imply that the Love head is placed toward the right. The point marking the head's axis thus falls on the left groove of the fork, showing that the copyist was interested in the main measurements of the piece and was not misled by the symmetry of the pattern.

Technically, there is a marked contrast between the rather superficial engraving of the dome strands and the deeply drilled furrows of the rolled curls. In the entire chignon the drill was extensively used to separate the various locks and create effects of light and shadow, but only the chisel seems to have been employed over the crown, with the result that a definite dichotomy prevails in the coiffure, making the upper part look perfunctory and almost unfinished, especially at the back. ${ }^{6}$ This treatment combines with the general rendering of the features to suggest that the head was meant to be seen from below, in a position which would have effectively hidden most of the crown from view. It is only in such a position that the face acquires proper depth and expression; seen full front from above, the facial traits appear shallow and superficial-especially the eyes-and the composition seems unbalanced. A drill of a smaller size was used to separate the lips and mark the inner corners of eyes and mouth.

The Love head was first considered an Amazon of the Luku type ${ }^{7}$ but was then recognized as a copy of the so-called Barberini Suppliant in the Louvre. ${ }^{8}$ In comparison with the statue in Paris, the Love head appears younger, somewhat boyish and more delicate; the face is shorter, more rounded, and nose and mouth seem smaller in proportion to the other features. The greatest contrast occurs in the rendering of the eyes, which in the French monument appear almost hollow under the deep shadow of the thin lids. In the Love head the lids are thicker, with more regular arcs which convey none of the almost pathetic effect of the Barberini eyes; the eyeballs are prominent and superficial, and give the impression of being too shallowly set within the head itself. ${ }^{9}$ It is interesting to note that the Barberini Suppliant was also intended to be seen from below ${ }^{10}$ and that both the Paris and the

slightly over lifesize.

9 A head of a Victory from the temple of Rome and Augustus in Ostia (Ostia Museum inv. no. I234), of Julio-Claudian date, seems to have the same shallow treatment of the eyes combined with deep inner corners. We are most grateful to Prof. Maria Floriani Squarciapino for the following information: this head was stolen from Ostia in 1940 and was at some point in the Carl Milles Collection, when it was published by A. Andren in OpusRom 5 (1965) I 03 no. 23, pl. 25. In 1966 Sweden returned the head to Italy and it is now on temporary display in the Ostia Museum, awaiting fuller discussion in a forthcoming work by Prof. Floriani Squarciapino. Unfortunately the photograph illustrated by Andren was taken from a definite angle which does not properly convey the rendering of the eyes noticeable in a direct examination of the piece.

The same superficial rendering appears also in a number of statues in North African museums, mostly unpublished.

10 This observation is made by Michon (supra n. 8) II8, Mingazzini (infra n. 18 ) and others. 
New York heads change expression and appearance when viewed from different angles.

A striking similarity between the two pieces is created by the hair renderings, which correspond almost lock by lock. ${ }^{11}$ Also the Barberini maiden juxtaposes a shallowly engraved crown to a plastic wreath of wavy curls, though the dichotomy here is not as pronounced as in the Love head. In profile, the rising and sinking of the dome hair is more noticeable in the Paris than in the New York replica, but the detailing of the strands is almost identical. The hair roll in both is characterized by an emphasis on semicircular, almost festoon-like forms, of which the most prominent is the large wave to the proper left of the part: it rises above the level of the fillet and hides it from view, though the ribbon reappears between the succeeding curls. There seems to be no question that in this respect the Love head has been closely patterned after the Barberini head or its prototype.

Does this similarity automatically imply forgery? Other ancient statues exist, copying the same Greek original, in which correspondence of hair pattern does not incur suspicion. ${ }^{12}$ Similarity of pattern, moreover, does not necessarily imply similarity of execution. Indeed, the master of the Love head seems to have used his drill a great a great deal more freely than the Barberini master. It must be stressed, however, that the channels bored into the New York head are much more noticeable now that the surface detailing of the strands has disappeared with the corrosion of the marble; the present contrast of smooth plastic forms and drilled shadowy furrows in between them was probably once considerably less prominent.

If comparison with the Barberini Suppliant supports the identification and perhaps even the authenticity of the Love head, comparison with acknowledged forgeries strengthens this position. Among the fakes, the most obvious is perhaps the head in the Terme; ${ }^{33}$ its hair is much more linear, cold and artificial, the dome swings too high above the fillet, the face is heavy, undetailed, with a rounded chin, and the neck looks awkward. In a word, the Roman piece displays none of the sensitivity present in the Love head. The head in the Musée Bonnat in Bayonne, though doubted by some, has been accepted as genuine by others. ${ }^{14}$ Its

11 This correspondence definitely exists in the front, but not so much in the back, where the Louvre piece lacks the symmetric, conventionalized "wishbone" effect of the Love hair pattern. On the other hand a very similar rendering appears in the Apollo from Cherchel, even to the detail of the parting falling to one side of the central axis over the nape. This similarity of hair rendering has also been noticed by Dörig (supra n. I) 235, who attributes both the Apollo and the Barberini Suppliant to Kalamis.

It should also be noted that the Love head differs from the Paris statue also in the fullness of the hair behind the ears; the Barberini's curls seem notably fuller and actually appear to push the ears out slightly.

12 Witness, for instance, the many replicas of the so-called Kassel Apollo recently studied by E.-M. Schmidt, Antike Plastik $\mathrm{V}(1966)$. rendering, to judge from photographs, seems more coloristic than either the Paris or the New York replicas, and the face has a sweeter expression. The other forgeries mentioned by Dörig are not illustrated; it should, however, be mentioned that at least some of them differ in dimensions from the Paris monument, being either considerably larger or smaller, and one is even of an unlikely material (alabaster).

Among the accepted replicas of the type are the headless statue in Leningrad and the one in the Vatican with non-pertinent head..$^{15}$ Obviously genuine heads for these genuine copies must have existed, and therefore one cannot a priori assume that all extant isolated heads of this type are fakes, even if the subject seems to have been a favorite of modern forgers. At this point it might be useful to note that in our opinion even the Barberini Suppliant, so often considered a Greek original, is a Roman copy: witness especially the rendering of the eyes which is not in keeping with true fifth century carving but recalls Augustan art. The Love head may also belong to the same period of copyists' activity, especially for its undefinable quality that vaguely reminds one of idealized JulioClaudian portraits. ${ }^{16} \mathrm{~A}$ good comparison with the Love head, both in technical details and artistic expression, is the head of Tellus in the Ara Pacis panel. ${ }^{17}$ Under the circumstances, we feel that the burden of proof lies with those who doubt the Love head's authenticity.

Other points remain open for discussion, which involve the type as a whole rather than the Love head specifically. Most prominent in the literature, and perhaps the least likely to be solved, is the problem of identification. The question has lately been restudied by Dörig, who suggests that the figure represents the Alkmena by Kalamis, and by Mingazzini ${ }^{18}$ who sees it as Iphigeneia. Fuchs ${ }^{19}$ accepts Mrs. Karouzou's identification as Danae. ${ }^{20}$ Other suggestions have included a Suppliant at an altar (hence the nickname), a Maenad, a frenzied Pythia, an Erinys, Penelope, the wife of Protesilaos, Kallisto and other major mythological personages. Though each of these identifications has some merit, the detail of the unshod foot and the arrangement of the base remain hard to explain.

The attribution of the sculpture to a master is

\section{Paribeni (supra n. 2).}

${ }^{14}$ See Dörig (supra n. I) for the dissenters; the head, published by $H$. von Buttlar, MarbWinckPr (1947) 5-8, fig. 6, has received Schuchhardt's approval (Gnomon 30 [1958] 490).

15 Waldhauer, Ermitage III, no. 26I ; Lippold, Vat.Kat. II, no. 393, cf. Helbig, Führer ${ }^{4}, 99$ no. I33, most recently discussed and illustrated by Dörig (supra n. I) pp. I 43-I 66, figs. $2-3$.

${ }^{16}$ See for instance the Livia in the Lateran or the Agrippina the Elder (?) in the Capitoline, R. West, Römische PorträtPlastik (Munich 1933) pls. 31:129 and 44:19I.

17 G. Moretti, Ara Pacis Augustae (1948) pl. 22. See also supra n. 9 .

${ }^{18}$ Dörig (supra n. I) I43-166; P. Mingazzini, "Un tentativo di esegesi della Supplice Barberini," AntK II (1968) 53-54.

${ }^{19}$ In Helbig, Führer, no. 133.

${ }^{20} \mathrm{BCH} \mathrm{6}_{4}-65$ (I940-4I) 25I-252; $\mathrm{BCH} 70$ (1946) 44I-442. 
equally controversial. Dörig has suggested the Boeotian Kalamis (p. I62), Karouzou the famous Polykleitos, ${ }^{21}$ Schuchhardt not the master himself but a pupil of the Argive school. ${ }^{22}$ Again, it is impossible to be sure.

But the one point of virtually unanimous agreement is the dating: ca. 430 в.c. This chronology is usually advocated on the basis of the similarity between the Barberini Suppliant and the reclining goddesses on the East pediment of the Parthenon, ${ }^{23}$ but support is most often sought in the works of fifth century playwrights and the dates of their performance, according to the identification favored for the statue. Since, however, this varies from scholar to scholar, the ultimate criterion remains stylistic evaluation, and it is encouraging to see different authors come to the same conclusions.

If the date of the Barberini type may be considered more or less fixed, we can use its elements as representative of a certain phase in Greek sculpture and as basis for speculation on earlier and later developments. Particularly interesting in this respect is the Suppliant's coiffure, since, by and large, fifth century originals occur either as headless bodies or as disembodied heads, and the evidence is difficult to correlate. The following notes therefore represent a tentative scheme of evolution in fifth century female coiffures based on the Barberini Suppliant's hairstyle.

The Severe Period knows a linear, decorative arrangement in which the hair is parted in the center and descends toward the temples in long wavy strands which frame the forehead in a roughly triangular pattern. The waves are large, usually limited to two on either side of the part before they reach the level of the eyebrows. The typical example of this style, which may be termed "the ogival canopy coiffure," appears ca. 460 в.c. on the so-called Aspasia/Sosandra type. ${ }^{24}$ This arrangement, though less linearly, continues in fashion down to the last quarter of the fifth century, both for female and for very young male figures: it can be seen, for instance, on a female head in a private Swiss collection, ${ }^{25}$ on the head of the young servant in the so-called Cat-stele, ${ }^{26}$ on a female head attributed to the same master ${ }^{27}$ and on other monuments. The basic hallmark of this fashion consists in the parallel course of the long strands, which tend to continue along the forehead without definite overlapping.

\footnotetext{
${ }^{21} \mathrm{BCH}^{6}$-65 (I940-4r) $25 \mathrm{I}$.

22 Gnomon (supra n. I).

${ }^{23}$ Figures L and M; F. Brommer, Die Skulpturen der Parthenon-Giebel (Mainz 1963) pls. 48-49.

${ }^{24}$ See for instance the unfinished statue from Baiae, J. Boardman, J. Dörig, W. Fuchs and M. Hirmer, The Art and Architecture of Ancient Greece (London 1967) pl. I70; or an even more linear rendering in the head of the same type from Gortyna, Festschrift Wegner (1962) pl. 9.

${ }^{25}$ AntK I I (r968) pl. 20:4.

${ }^{26}$ R. Lullies and M. Hirmer, Greek Sculpture (1960) pl. I 82.

27 N. Himmelmann-Wildschütz, MarbWinckPr (1956) pls. $\mathrm{I}$ and $\mathrm{I} 2$.

${ }^{28}$ Capitoline type: head in the Conservatori Museum, EAA IV, s.v. Kresilas, fig. 479. Lansdowne type: G. M. A. Richter, Catalogue of Greek Sculpture in the Metropolitan Museum of
}

A slightly different development from the same initial pattern involves instead a definite overlapping of the strands, which no longer follow the contour of the forehead but progressively tend to be swept back over the temples. The change begins with the famous Amazons: the so-called Capitoline type is closer to the "ogival-canopy" rendering, the Lansdowne type shows more overlapping, the individual strands are more difficult to follow from origin to end, and the wave pattern is strongly toned down. ${ }^{28}$ They are probably to be dated around 440 B.c. The so-called Cherchel Demeter, of approximately the same period or slightly later, shows instead an exasperation in the rhythm of the waves, which become higher and more frequent, though still following the ogival-canopy pattern. ${ }^{29}$ To the same stage of development belongs the so-called Prokne by Alkamenes: the face is damaged but the remains of the hair over the temples suggest a similar pattern of parallel waves. ${ }^{30}$ The next step is perhaps represented by the Laborde Head, which may come from the Parthenon pediments: ${ }^{31}$ the waves are smaller but still form a continuous, highly decorative scalloped border to the forehead. Unfortunately the piece is damaged in the area of the central part, but the rendering is clearly visible along the temples. The date of this work should fall between 438 and 432 в.c. The Barberini Suppliant represents a further development, in that the single strands are now seen to originate not only from the part but also from the sides. The overlapping is considerable but the waves are still rounded and undercut; the emphasis on "wavelets" of semicircular form is indeed the characteristic of this phase, which should perhaps be dated ca. 430-425 B.c. In support of this date we may perhaps bring the hairstyle of the Nike by Paionios, securely dated after 425 B.c. by its historical connections. The Nike's face is damaged and the hair is largely gone, but it is still preserved over the temples and, in a more linear, perhaps exaggerated form, in two Roman replicas. ${ }^{32}$ The final step within the fifth century is reached by the female head from the Argive Heraion and the Caryatids of the Erechtheion, ${ }^{33}$ where the central part happens to be replaced by a braid. But the significant element is the rendering of the temple strands, where all the kinks tend to disappear and the circular forms are toned down. ${ }^{34}$

Art, pl. 36. The main types are illustrated in EAA s.v. Amazzone, or in V. Poulsen, Die Amazone des Kresilas, Opus Nobile I (I957). All Amazonian coiffures seen dependent on the basic hair pattern, with minor variations.

${ }^{29}$ Dörig (supra n. I) figs. $83-86$, attributed by him to the same master of the Barberini Suppliant, Kalamis.

${ }^{30}$ For this detail see S. Adam, The Technique of Greek Sculpture (1966) pl. 39; the total figure in Boardman, Dörig, Fuchs and Hirmer (supra n. 24) pl. 229.

31 Brommer (supra n. 23) pl. I32.

32 G. M. A. Richter, Sculpture and Sculptors of the Greeks (1950) figs. 639-642. On the basis of this evidence the date of the Barberini Suppliant should perhaps be slightly lowered.

${ }^{33}$ Richter, Sculpture and Sculptors, figs. 165 and 502.

${ }^{34}$ It is true that the Caryatids, qua Caryatids, retain an oldfashioned coiffure, with nape braids and kore-like locks over 
In direct contrast with the festooned borders of the beginnings, crinkly strands growing almost at right angles to the forehead will characterize the next stages within the fourth century: a rendering ultimately to triumph in the Knidian Aphrodite by Praxiteles.

Ellen Herscher

Brunilde Sismondo Ridgway

UNIVERSITY OF PENNSYLVANIA

BRYN MAWR COLLEGE

\section{THE FELT SHOPS OF POMPEII ${ }^{1}$}

PLATE 46

Up to the present two felt shops, officinae coactiliariae, have been identified at Pompeii. They are both in the same insula and face on the Via dell'Abbondanza. Since they have not as yet been fully excavated, they are recognized only from the evidence on their façades: one (IX.vii.I) from an electoral notice of the felters; ${ }^{2}$ the other (IX.vii.5/7), known as the shop of Verecundus, from an electoral notice and a wall painting of felters at work. ${ }^{3}$ In the painting (pl. 46 , fig. I) is a furnace with two tables at the sides and four workmen at the tables kneading long sausages of wool. There must have been a pan on top of the furnace in which the sizing was kept warm and viscous. It should be emphasized that these identifications were made entirely from external evidence.

I believe, however, that two other officinae coactiliariae have been fully excavated in the city. In the summer of 1961 a small one-room shop (I.xii.4) was uncovered on the Via dell'Abbondanza (ill. I). Its only notable feature is an oval furnace, completely detached from the walls. The furnace has since been reconstructed to a height of about $53 \mathrm{~cm}$. (pl. 46 , fig. 2 ), but, as shown by its condition at excavation (pl. 46, fig. 3), there is no way of knowing how high it was originally. The shop has not as yet been published or identified, although some feel that it was devoted to the preparation of food, since it is located between two thermopolia. This idea, however, should be rejected, partly because the furnace is not well adapted to the preparation of food and there are no serving counters. What struck me upon seeing the location shortly after excavation was that the furnace is like the one portrayed on the façade of the shop of Verecundus. It could have been high enough to reach the waists of the Pompeian felters, who were short by modern standards. The girl in pl. 46 , fig. 4 is about $5^{\prime} 4^{\prime \prime}$ tall; but in any case the furnace might have been higher than the reconstruction. This shop, too, probably served as

the chest, but what matters in this context is the rendering of the hair itself, not the intricacies of its arrangement. It is interesting, in this connection, to note how the popularity of the Erechtheion must have influenced subsequent sculpture, so that the old-fashioned chest-locks reappear in the fourth century Eirene by Kephisodotos.

1 This note was presented as a paper at the Seventy-first Gen-

\section{OFFICINA COACTILIARIA POMPEII - I. xii. 4}
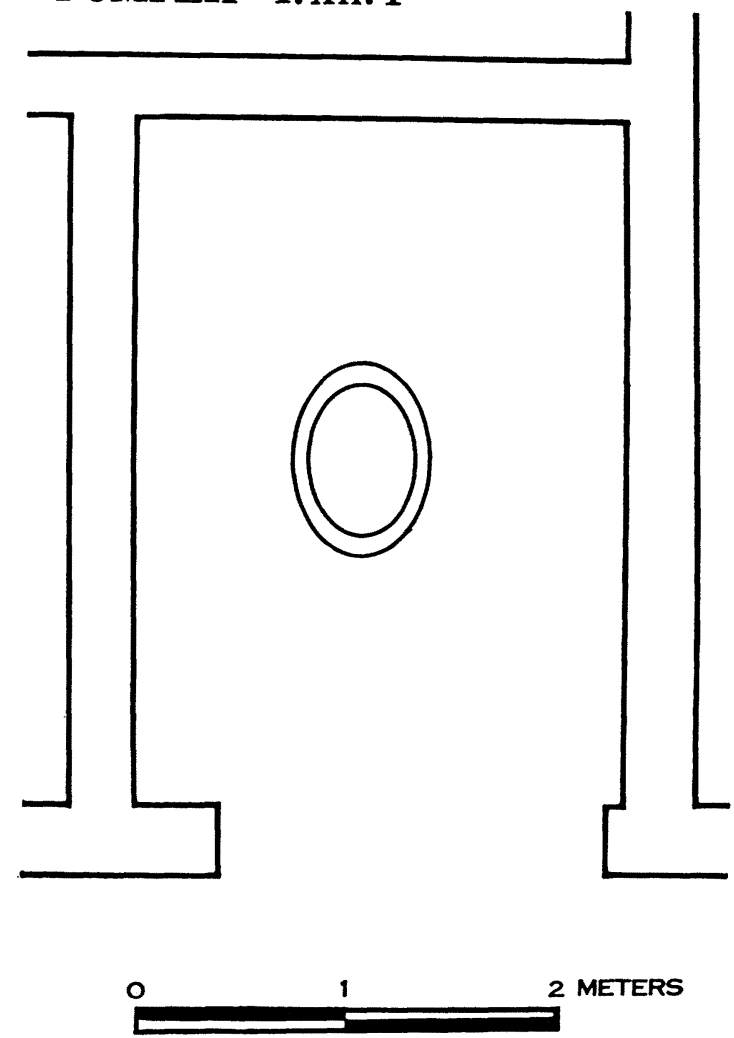

ILL. I. Author's plan of I.xii.4

a felting plant. To those who might object that there was no room for drying pieces of felt, it must be pointed out that this could have been done on the street, as is suggested by what appears to be a drying rack in another painting from the shop of Verecundus (pl. 46, fig. 5). ${ }^{4}$ The use of the street for industrial drying is common in the Mediterranean today and it undoubtedly was an ancient practice. To those who might object that an officina coactiliaria would not have been placed next to food shops, I can only say that this is imposing our standards on the Romans; a people who had no qualms about building latrines in kitchens would not have been excessively bothered by having a felt shop next to thermopolia.

The other fully excavated shop (IX.iii.r6) has two rooms with a detached furnace in the front room (ill. 2). Unfortunately there is no trace of the furnace left,

eral Meeting of the Archaeological Institute of America on December 29, 1969. It was made possible in part through a grant-in-aid from Temple University. I wish to thank Professor Alfonzo de Franciscis, Superintendent of Antiquities in Campania, for permission to publish location I.xii.4.

${ }^{2}$ M. Della Corte, Case ed abitanti di Pomper (Rome 1964) 282; CIL IV 7809 .

3 Della Corte $278 \mathrm{f}$; CIL IV 7838.

${ }^{4}$ Della Corte 279. 

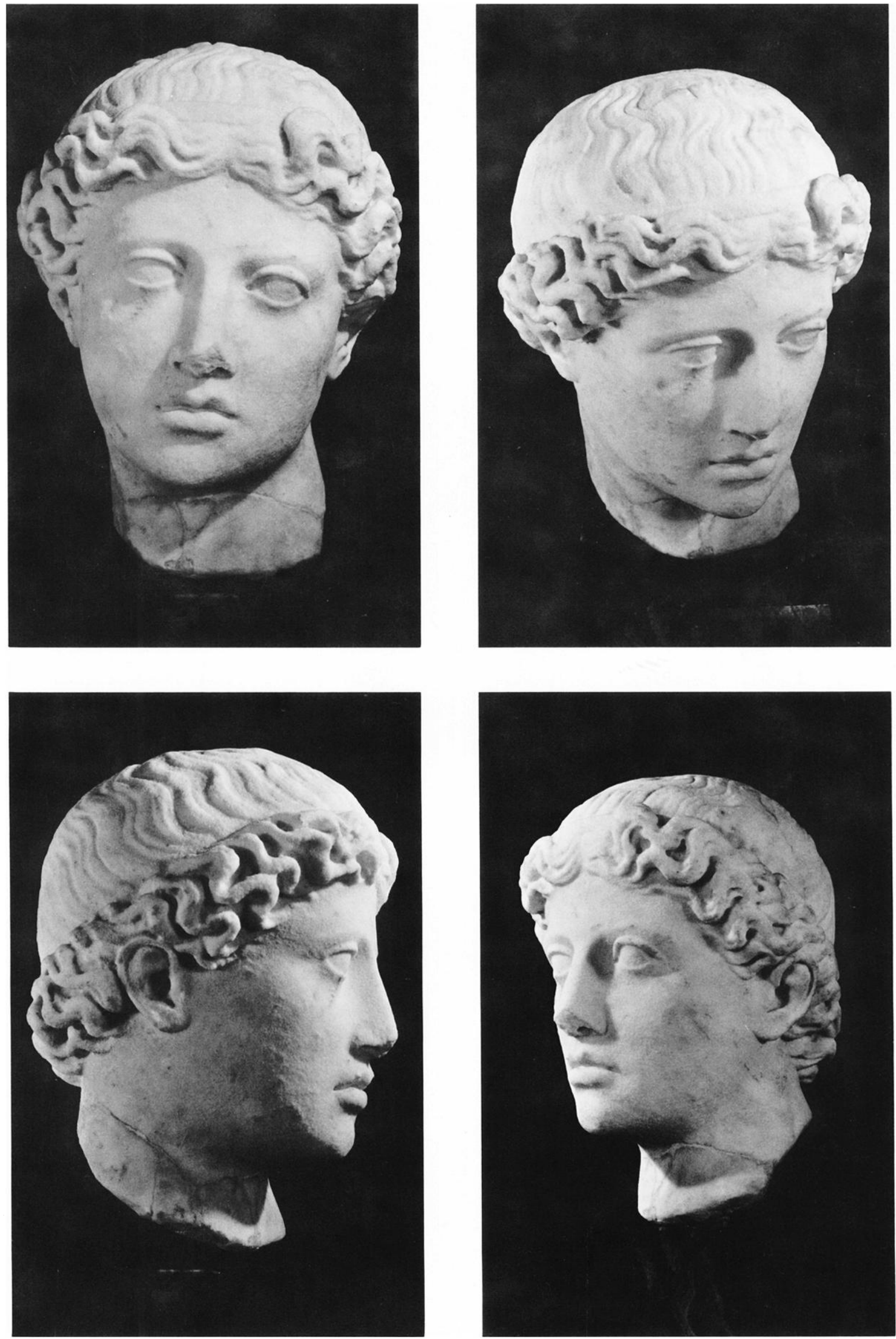

New York, Love Collection 